\title{
Optical parameters of milk fat globules for laser light scattering measurements
}

\author{
Marie-Caroline MichalskI*, Valérie BRIARD, Françoise Michel \\ Laboratoire de Recherches de Technologie Laitière \\ INRA, 65 rue de Saint-Brieuc, 35042 Rennes Cedex, France
}

(Received 7 March 2001; accepted 29 June 2001)

\begin{abstract}
This study presents milk fat globule refractive index $\left(\mathrm{n}_{\mathrm{i}}\right)$ and absorption coefficient $\left(\mathrm{k}_{\mathrm{a}}\right)$ values that can be used reliably for particle size distribution measurements by Laser Light Scattering at two different wavelengths. $\mathrm{A} \mathrm{k}_{\mathrm{a}} \approx 10^{-5}$ was obtained for liquid milk fat. The $\mathrm{n}_{\mathrm{i}}$ of milk fat globules at $20^{\circ} \mathrm{C}$ was measured at $589 \mathrm{~nm}$ and was calculated to be 1.470 at $466 \mathrm{~nm}$ and 1.460 at $633 \mathrm{~nm}$. Because the software of the LLS equipment does not allow for differences in $n_{i \text {,water }}$ at the two different wavelengths, $n_{i, \text { fat }}$ was corrected to reflect the difference between the refractive indices of the fat globule and its surrounding medium at each wavelength. For example, if $\mathrm{n}_{\mathrm{i} \text { water }}$ is taken to be 1.33 , then for milk fat globules the corrected value is 1.458 at $633 \mathrm{~nm}$ and 1.460 at $466 \mathrm{~nm}$. These optical parameters led to reliable milk fat globule size distributions. In any case, $\mathrm{k}_{\mathrm{a}}$ must never be overestimated, since this leads to artefactual peaks.
\end{abstract}

milk fat / fat globule / refractive index / particle size distribution / laser light scattering / optical property

Résumé - Propriétés optiques des globules gras du lait pour les mesures en granulométrie laser. Dans cette étude, nous présentons des valeurs de l'indice de réfraction $\left(\mathrm{n}_{\mathrm{i}}\right)$ et du coefficient d'absorption $\left(\mathrm{k}_{\mathrm{a}}\right)$ des globules gras du lait, à deux différentes longueurs d'onde, qui sont fiables pour des mesures de granulométrie laser à diffraction de la lumière. Une valeur de $\mathrm{k}_{\mathrm{a}} \approx 10^{-5}$ est obtenue pour la matière grasse laitière liquide. L'indice $\mathrm{n}_{\mathrm{i}}$ des globules gras à $20^{\circ} \mathrm{C}$ est mesuré à $589 \mathrm{~nm}$; sa valeur calculée est alors de 1,470 à $466 \mathrm{~nm}$ et 1,460 à $633 \mathrm{~nm}$. Comme il n'est pas possible d'entrer des valeurs de $\mathrm{n}_{\mathrm{i}, \text { eau }}$ différentes pour les deux longueurs d'ondes $\lambda$, on utilise des valeurs corrigées de $\mathrm{n}_{\mathrm{i}, \text { globule }}$ pour maintenir correcte la différence d'indice de réfraction entre les globules gras et l'eau à chaque $\lambda$. Par exemple, si l'on considère $\mathrm{n}_{\mathrm{i}, \text { eau }}=1,33$ pour les deux $\lambda$, alors pour les globules gras la valeur corrigée est de 1,458 à $633 \mathrm{~nm}$ et 1,460 à $466 \mathrm{~nm}$. Ces paramètres optiques permettent d'obtenir des distributions granulométriques fiables pour les globules gras du lait. La valeur de $\mathrm{k}_{\mathrm{a}}$ ne doit jamais être surestimée car cela entraîne l'apparition de populations artéfactuelles.

matière grasse du lait / globule gras / indice de réfraction / distribution de taille de particule / granulométrie laser / propriété optique

* Correspondence and reprints

Tel.: (33) 2234853 22; fax: (33) 2234853 50; e-mail: mcmichal@labtechno.roazhon.inra.fr 


\section{INTRODUCTION}

Milk fat is present in milk as droplets of diameter in the range $1-10 \mu \mathrm{m}$, with a maximum around $4 \mu \mathrm{m}$, depending on cow breed and season [10]. However, when milk is subjected to severe mechanical treatments such as homogenization, the fat globules are disrupted and their average diameter decreases dramatically (typically to $1 \mu \mathrm{m})$. The increase of interfacial area that cannot be covered by the original milk fat globule membrane anymore is made up by the adsorption of casein micelles and whey proteins on the newly formed surface [10]. Studies concerning the size distribution of natural milk fat globules are not very recent. They used methods such as scanning electron microscopy, spectroturbidimetry, fluorescence microscopy [18], microscopy [9], the Coulter counter [18] and a few using electroacoustics [14] or Laser Light Scattering (LLS) [8]. The size distribution of homogenized milk fat globules has originally been determined by spectroturbidimetry and the Coulter counter [7]. In recent years, LLS and Dynamic Light Scattering have been the preferred techniques for the particle size determination of milks homogenized regularly or by microfluidization $[8$, 13].

LLS techniques are based on the Mie theory [6] to calculate the size distribution of particles from their light scattering pattern. The latter depends greatly on the optical properties of the particles, namely, their refractive index. The refractive index is a complex number:

$$
\hat{\mathrm{n}}_{\mathrm{i}}=\mathrm{n}_{\mathrm{i}}+\mathrm{i} \cdot \mathrm{k}_{\mathrm{a}}
$$

where the real part $n_{i}$ is the regular refractive index as measured with a refractometer, and the imaginary part $\mathrm{k}_{\mathrm{a}}$ is the light absorption coefficient. $\hat{\mathrm{n}}_{\mathrm{i}}$ depends both on temperature and wavelength; without any specification, the refractive index of a substance is taken as $589 \mathrm{~nm}, 20^{\circ} \mathrm{C}$. Any error in refractive index values chosen for calculations leads to wrong particle size distributions. This in turn induces large errors for the specific surface area, for example. In new LLS apparatus (Malvern MasterSizer 2000, Malvern, UK), two laser sources are used to account for retrodiffusion effects and enhance sensitivity for particles down to $50 \mathrm{~nm}$. Moreover, it becomes possible to enter the exact optical properties of the particles studied at the two different wavelengths (466 and $633 \mathrm{~nm}$ ). The results obtained using the latest version of the Mastersizer are thus likely to be more accurate, because the software allows a more accurate specification of the optical properties of particles. Only a few results are to date available about the milk fat globule refractive index $n_{i}$, with the studies by Walstra $[16,21]$. Moreover, results for $n_{i, \text { fat }}$ were most of the time presented at $589 \mathrm{~nm}$ and absorption coefficient values were seldom shown in general literature concerning milk fat. Therefore, there was a need to publish values of milk fat globule $\mathrm{n}_{\mathrm{i}}$ and $\mathrm{k}_{\mathrm{a}}$ for LLS users.

The aim of the present study was to estimate the average milk fat globule refractive index and absorption coefficient to obtain accurate laser light scattering results.

\section{MATERIALS AND METHODS}

\subsection{Materials}

Raw whole summer milk was collected from four sources: uncooled mixed milk from 8 cows from a local herd (Mellon, Pacé, France), cooled mixed milk (also called processed milk) from local dairy plants (Montauban-de-Bretagne, France and Triballat, Noyal-sur-Vilaine, France) and cooled milk (unmixed) from four cows of our experimental farm, with different feed. Measurements were also performed using milk homogenized in a two-stage homogenizer (nmGEN 7400H, Stansted, 
Essex, UK) at a pressure of $10 \mathrm{MPa}$ at the first head and $2 \mathrm{MPa}$ at the second head. When necessary, fat content was determined using an infrared analyzer (Dairylab, Foss Electric, Nanterre, France) and by the Gerber method. Anhydrous milk fat (AMF) was purchased from Fléchard (La Chapelle d'Andaine, France). EDTA ( $>98 \%$, disodium salt, $2 \mathrm{H}_{2} \mathrm{O}$, Prolabo, France) and urea (Merck, Darmstadt, Germany) were used as casein dissociating agents for particle size measurement [8] and SDS (sodium dodecyl sulfate, approx. 99\% for Gas Chromatography, Sigma, Saint-Louis, USA) was used to dissociate fat globule clumps. Diethanolamine with purity $>99.5 \%$ (Normapur, Prolabo, France) was used for milk fat globule refractive index determination.

\subsection{Measurement of the milk fat absorption coefficient}

The milk fat absorption coefficient $\left(\mathrm{k}_{\mathrm{a}}\right.$, imaginary part of the refractive index) was determined using fat extracted from whole milk according to [2] and AMF. Two sources of fat were used to take into account the effect of different milk fat compositions and extraction procedures. Milk fat was melted at $65^{\circ} \mathrm{C}$ and transferred in $1 \mathrm{~mm}$-lightpath cuvettes at $20^{\circ} \mathrm{C}$ (Hellma, from Merck-Eurolab, Darmstadt, Germany) using a micropipette. The optical density of liquid milk fat was measured at $20^{\circ} \mathrm{C}$ with a UV-visible spectrophotometer (Uvikon 922, Bio-Tek Kontron Instruments, St-Quentin-en-Yvelines, France) from 400 to $700 \mathrm{~nm}$.

The absorption coefficient $\mathrm{k}_{\mathrm{a}}$ is linked to the specific extinction coefficient $\mu[6,16]$ :

$$
\mathrm{k}_{\mathrm{a}}=\mu \cdot \lambda / 4 \pi
$$

where $\lambda$ is the wavelength. From the BeerLambert equation for a purely absorbing medium, $\mu$ is related to the sample optical density (D) and the lightpath length (h):

$$
\ln \left(\mathrm{I}_{0} / \mathrm{I}\right)=\mathrm{D} \cdot \ln 10=\mu \cdot \mathrm{h} .
$$

Accordingly, $\mathrm{k}_{\mathrm{a}}$ was calculated using:

$$
\mathrm{k}_{\mathrm{a}}=(\mathrm{D} \cdot \lambda \cdot \ln 10) /(4 \pi \cdot h) .
$$

\subsection{Measurement and calculation of the milk fat globule refractive index}

For the milk fat globule refractive index determination $\left(\mathrm{n}_{\mathrm{i}}\right)$, the index-matching method of Walstra [16] and Griffin and Griffin [3] was used. In this method, milk fat globules are dispersed in more than one medium having different refractive indexes. The dispersion's optical density is at its lowest value when the medium has a similar refractive index to that of the fat globules. In this study, mixtures were used of diethanolamine $\left(\mathrm{n}_{\mathrm{i}}=1.476\right.$ at $589 \mathrm{~nm}$, $\left.20{ }^{\circ} \mathrm{C}\right)$, water $\left(\mathrm{n}_{\mathrm{i}}=1.33\right.$ and milk fat globules in the liquid state.

Different sources of milk fat globules were used, to test the influence of the medium surrounding milk fat globules and globule membrane composition on $\mathrm{n}_{\mathrm{i}}$ results:

- Original raw whole milk.

- Milk fat globules washed of the plasma by the gentle washing method of Patton and Houston [12] $(10 \mathrm{~mL}$ of milk with $5 \%(\mathrm{w} / \mathrm{v})$ sucrose were placed under $30 \mathrm{~mL}$ of buffer $-20 \mathrm{mmol} \cdot \mathrm{L}^{-1}$ imidazole, $50 \mathrm{mmol} \cdot \mathrm{L}^{-1} \mathrm{NaCl}, 5 \mathrm{mmol} \cdot \mathrm{L}^{-1} \mathrm{CaCl}_{2}$, $\mathrm{pH} \mathrm{7-}$ and centrifuged for $20 \mathrm{~min}$ at $1500 \mathrm{~g}$ ). Washed cream was diluted in the buffer to obtain a fat concentration like that in milk.

- Milk homogenized at a pressure of $10 \mathrm{MPa}$ as described above.

The mixtures contained $2 \% \mathrm{v} / \mathrm{v}$ milk, from 82 to $98 \%$ diethanolamine, and water. The volumic fraction of the dispersed phase was thus always less than $10^{-3}$, as indicated by Walstra [17]. The optical density D of 
the mixture was readily measured at $589 \mathrm{~nm}$ using the spectrophotometer described above. Their refractive index was measured at $20^{\circ} \mathrm{C}\left( \pm 0.3^{\circ} \mathrm{C}\right)$ using an Abbe refractometer. Plotting $\mathrm{n}_{\mathrm{i} \text {,mixture }} \cdot \sqrt{\mathrm{D} / \mathrm{C}_{\text {milk }}}$ vs $\mathrm{n}_{\mathrm{i} \text {,mixture }}$ [16], the $x$-value where the ordinate was minimum corresponded to the milk fat globule refractive index, at $589 \mathrm{~nm}$.

Since $\left(\mathrm{n}_{\mathrm{i}}{ }^{2}+2\right) /\left(\mathrm{n}_{\mathrm{i}}{ }^{2}-1\right)=a \cdot \lambda^{-2}+b$ (linear function of $\lambda$ ) [21], it follows that:

$$
\mathrm{n}_{\mathrm{i}}=\sqrt{\frac{(b+2) \cdot \lambda^{2}+a}{(b-1) \cdot \lambda^{2}+a}} .
$$

Nearly parallel regression lines of $n_{i}=f(\lambda)$ were found by Walstra for butterfat at $35{ }^{\circ} \mathrm{C}$ and tricaproin and triolein at $20{ }^{\circ} \mathrm{C}$ [16]. Therefore, the slope $(a)$ was considered to be constant at -0.03 , from the literature [21]. Parameter $b$ was calculated using the refractive index measured at $589 \mathrm{~nm}$. Then, the above equation was used to calculate $n_{i}$ at 633 and $466 \mathrm{~nm}$.

\subsection{Size distribution measurements}

The milk fat globule size distribution was determined by LLS using the Mastersizer 2000 (Malvern Instruments, Malvern, UK) that works with a $\mathrm{He} / \mathrm{Ne}$ laser at $633 \mathrm{~nm}$ and an electroluminescent diode at $466 \mathrm{~nm}$. Laser alignment was performed in $\mathrm{mQ}$ water. Each sample was measured by diluting $\left(1: 1 \mathrm{vol}\right.$.) with $35 \mathrm{mmol} \cdot \mathrm{L}^{-1}$ EDTA/NaOH, pH 7.0 buffer to dissociate casein micelles and aggregates, then dispersing a small volume (using a precision pipette) in the sample unit containing $100 \mathrm{~mL}$ of $0.1 \%$ SDS solution in mQ water. The volumetric size distribution was calculated by the software.

The absorption coefficient and refractive index for the milk fat globules at 466 and $633 \mathrm{~nm}$ were taken as presented in the Results section. Unfortunately, for the dispersant, it is still not possible to enter a refractive index for both wavelengths in the
Malvern software. This gap is likely to cause some uncertainty. The refractive index of water at $633 \mathrm{~nm}$ was taken to be 1.33; but we could not consider its value at $466 \mathrm{~nm}$ (1.338) [1]. It was checked that the $0.1 \%$ SDS solution did not cause any significant shift in the water refractive index.

\section{RESULTS AND DISCUSSION}

\subsection{Milk fat absorption coefficient}

The absorption coefficient of milk fat at wavelengths of interest, for melted fat, are shown in Table I; examples of $\mathrm{k}_{\mathrm{a}}$ variation with wavelength are shown in Figure 1. For the sake of comparison, $\mathrm{k}_{\mathrm{a}}=2 \times 10^{-3}$ for bitumen droplets [4]. Even if the absorption by milk fat is small, it derserves a careful estimation. Our results are consistent with Walstra [16] who found approximately $\mathrm{k}_{\mathrm{a}}=10^{-5}$ at $466 \mathrm{~nm}$ and $0.5 \times 10^{-5}$ at $500 \mathrm{~nm}$ for melted milk fat (estimated from a figure). Discrepancies sometimes appearing in the results at $466 \mathrm{~nm}$ come from the fact that close to the UV region, different contents in unsaturated triglycerides can result in variations in $\mathrm{k}_{\mathrm{a}}$. The optical density of crystallized milk fat (due to both absorption and scattering by crystals) leads to an overestimated $\mathrm{k}_{\mathrm{a}}$ value of around $10^{-4}$ (by

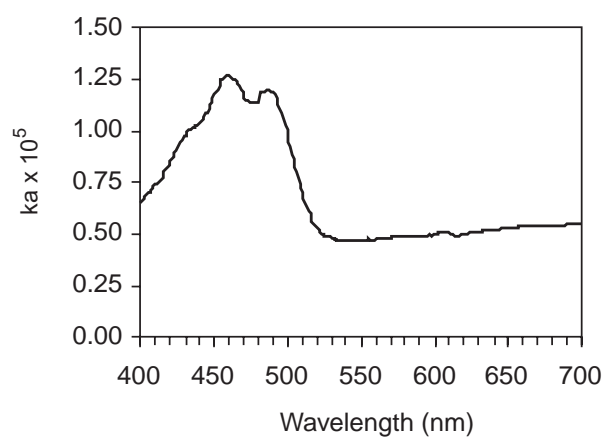

Figure 1. $\mathrm{k}_{\mathrm{a}}$ variation with wavelength for liquid fat (point example). 
making the wrong approximation that scattering is due to absorption only), which is still very small. It is known that the milk fat triglycerides crystallize in various polymorphic forms, depending on cooling rate, and that crystallization is not homogeneous among fat globules [19]. The resulting light scattering and absorption by crystals will thus depend on the thermal past of the product. It is thus not advised to use partially crystallized fat globules for LLS measurements, since the $\mathrm{k}_{\mathrm{a}}$ value is then not known with certainty.

\subsection{Milk fat globule refractive index}

The graphic determination of the milk fat globule refractive index $n_{i}$ at $20{ }^{\circ} \mathrm{C}$, using raw whole milk, is presented in Figure 2. Our value $n_{i}=1.461$ is somewhat lower, but of the same order of magnitude, as that published by Walstra at $589 \mathrm{~nm}$ (1.462 [10] and 1.4628 [16]). This small discrepancy can be due to variations in cow feeding from that time, that affects the milk fat composition and consequently the refractive index. For instance, a variation of milk fat globule refractive index in the order of $1.5 \times 10^{-3}$ was once observed between summer and winter milks, and of $1.1 \times 10^{-3}$ among fat globules in mixed milks [20]. Because refractive index increases with triglyceride unsaturation [11, 19], our results would reflect a greater proportion of saturated triglycerides. The minimum y-value may differ from zero due to milk concentration, residual casein micelles and discrepancy among individual fat globules. The same refractive index was found for uncooled milk from a farm and for cooled mixed milk heated to $50{ }^{\circ} \mathrm{C}$ to melt the fat prior to measurements at $20^{\circ} \mathrm{C}$. It should be stressed that we did not observe

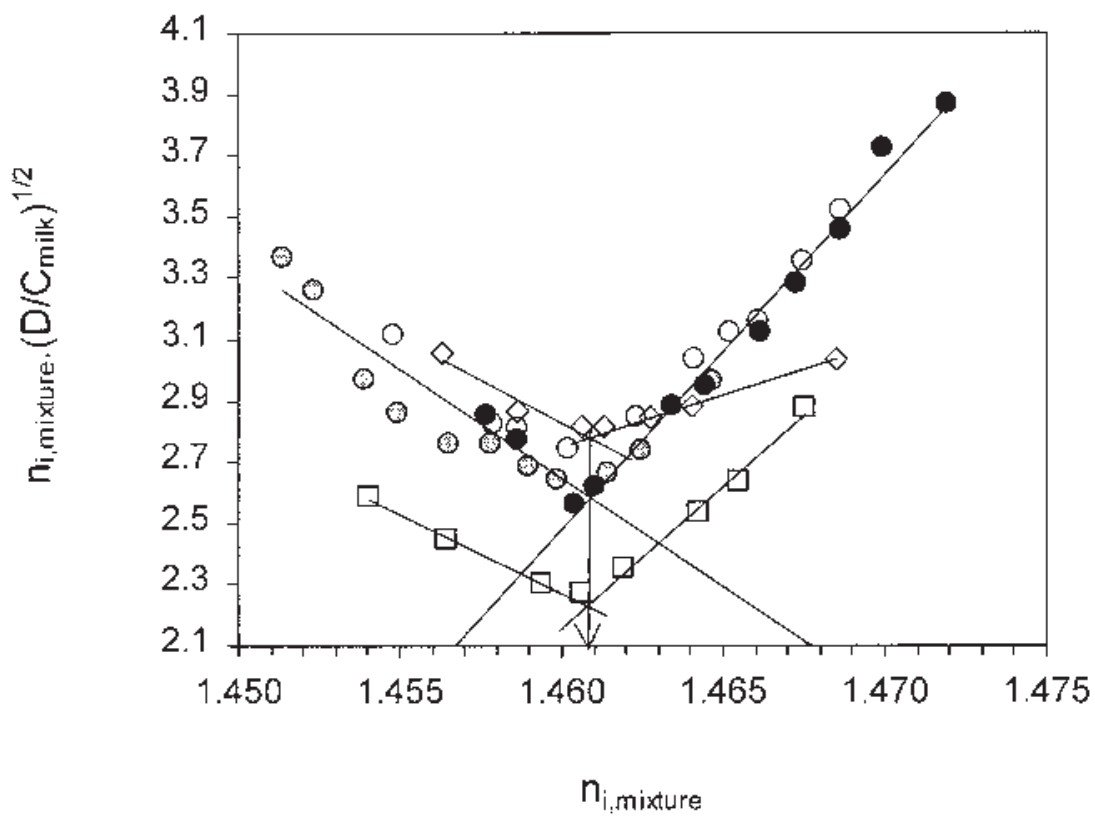

Figure 2. Estimation of the milk fat globule refractive index. (o) Raw (different colors represent different milks), $(\square)$ washed, and $(\diamond)$ homogenized globules. See text for explanations. 
any significant change in the refractive index neither after washing the fat globules from most of the casein micelles $\left(\mathrm{n}_{\mathrm{i} \text {,casein }} \approx\right.$ 1.57 according to Griffin and Griffin [3]), nor after homogenizing milk at $10 \mathrm{MPa}$. This means that the same refractive index may be used for laser light scattering experiments of homogenized milk fat globules, especially since their membrane is made thinner by the action of the casein dissociating agent. The minimum y-value is lower for washed globules because there are less residual micelles. For homogenized milk the minimum y-value is slightly higher due to the higher turbidity of homogenized milk, that contains smaller globules. From calculations presented in the Methods section, the parameter $b$ was 3.725 (the value from the literature was 3.77 [21]). Consequently, we found $n_{i}=1.460$ at $633 \mathrm{~nm}$ and $\mathrm{n}_{\mathrm{i}}=1.470$ at $466 \mathrm{~nm}$ (corresponding to a dispersion coefficient $\sim 52$ ). These values may be considered with a standard deviation of $10^{-3}$.

\subsection{Correction of refractive index values for light scattering measurements}

The magnitude of the light scattering coefficient for a population of fat globules of average Sauter diameter $\mathrm{d}_{32}$ is given by the parameter $2 \pi \cdot d_{32} \cdot\left(n_{i, \text { fat }}-n_{i, \text { water }}\right) / \lambda[15]$. Ac- cordingly, the important parameter for LLS measurements is the difference between the refractive index of milk fat globules and that of water. As specified in the Methods section, the MS2000 apparatus does not allow the entry of the refractive index of water at both wavelengths: only 1.33 is used. Consequently, the correct way to use this LLS apparatus is to consider corrected values of $n_{i, f a t}$ at each wavelength, in such a way that:

$$
\mathrm{n}_{\mathrm{i}, \text { fat }(\lambda)}^{\text {corrected }}-1.33=\mathrm{n}_{\mathrm{i}, \text { fat }(\lambda)}^{\text {real }}-\mathrm{n}_{\mathrm{i}, \text { water }(\lambda)}^{\text {real }} \text {. }
$$

Corrected values are reported in Table I.

\subsection{Milk fat globule size distribution}

The raw milk fat globule size distribution (Fig. 3) obtained with the optical properties presented in the previous section is consistent with Walstra [18]. One difference, though, is that the distributions did not usually present any fat globule in the range $0.5-1 \mu \mathrm{m}$. However, using the multimodal analysis mode of the Malvern software (presence of multiple peaks) instead of the general mode (unknown distribution of spherical particles), a small peak appears at the beginning of the distribution. This peak represents $2.7 \%$ of the population's volume and its mean is $1.3 \mu \mathrm{m}$. It may

Table I. Absorption coefficient of milk fat $\left(\mathrm{k}_{\mathrm{a}}\right)$ and refractive index of milk fat globules $\left(\mathrm{n}_{\mathrm{i}}\right)$ calculated from spectrophotometric measurements and index matching at $20^{\circ} \mathrm{C}$.

\begin{tabular}{cccc}
\hline & $\mathrm{k}_{\mathrm{a}}\left(\times 10^{5}\right)$ & $\mathrm{n}_{\mathrm{i}}$ & $\mathrm{n}_{\mathrm{i}}{ }^{\text {corrected }}$ for LLS \\
\hline Wavelength $(\mathrm{nm})$ & Liquid fat $^{\mathrm{a}}$ & Milk fat globules & Milk fat globules \\
\hline 466 & $1.7 \pm 0.6$ & $1.470^{\mathrm{b}}$ & $1.460^{\mathrm{c}}$ \\
\hline 589 & $0.5 \pm 0.0$ & 1.461 & $1.458^{\mathrm{c}}$ \\
\hline 633 & $0.5 \pm 0.1$ & $1.460^{\mathrm{b}}$ & $1.458^{\mathrm{c}}$ \\
\hline
\end{tabular}

\footnotetext{
${ }^{\text {a }}$ After melting at $65{ }^{\circ} \mathrm{C}$.

${ }^{\mathrm{b}}$ Calculated from the measured value at $589 \mathrm{~nm}$ using equations by Walstra [16].

${ }^{c}$ Corrected value used if the refractive index of water is assumed to be 1.33 at both wavelengths in the LLS apparatus, according to Sect. 3.3.
} 

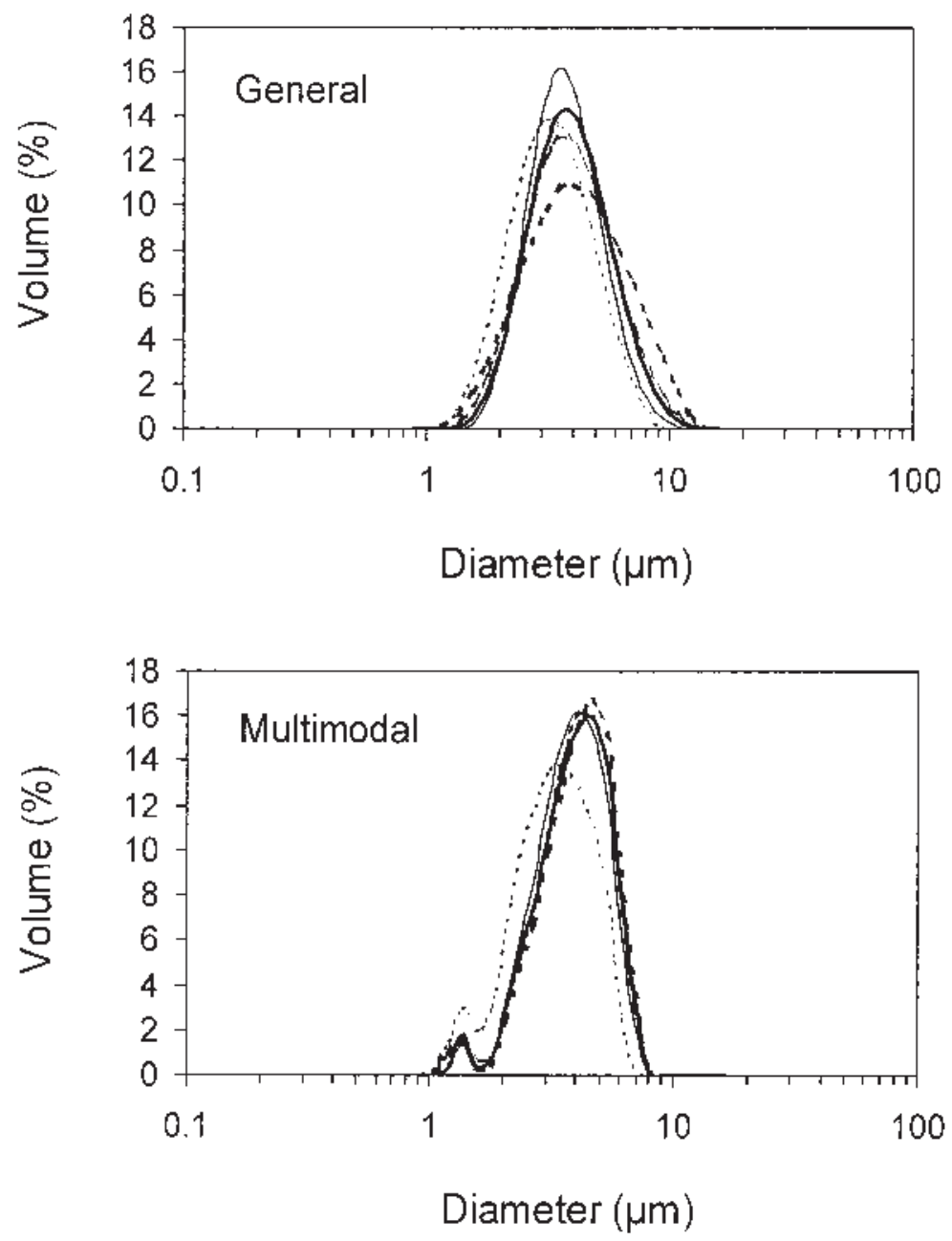

Figure 3. Point examples of milk fat globule size distributions obtained using the Mastersizer in the General and Multimodal modes, for milks collected from May to December.

be assimilated to the bottom of Walstra's distribution, even though it is probably exaggerated due to the multimodal algorithm. The log-normal distribution confirms the "tail" observed by Walstra at larger sizes. Sometimes, experimental farm milks presented a shoulder at small sizes (with the General analysis mode), corresponding to another globule population in the range $0.7-1 \mu \mathrm{m}$. This result suggests that the lower end of the size range may depend on cow feed.
A good correlation was obtained between the two following parameters: (i) the milk fat concentration apparently circulating in the apparatus as calculated by the software and (ii) the milk fat concentration actually circulating (Fig. 4). This shows that the chosen optical properties for milk fat globules were reliable. Measurements performed in water or in $0.1 \%$ SDS led to the same size distribution for natural fat globules, even if in SDS the weighted residual was not as good as in water (typically, 


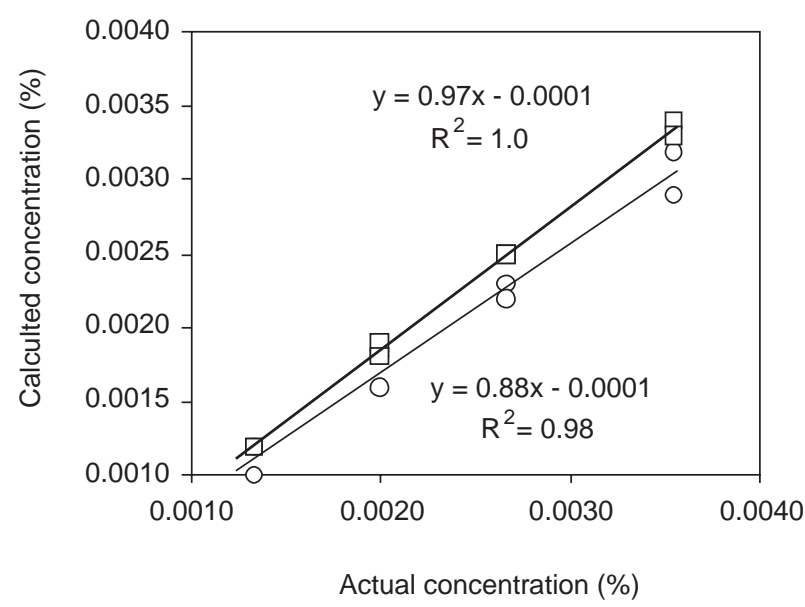

Figure 4. Correlation between the milk fat globule concentration in the LLS apparatus as calculated by the software and the actual concentration. (o) Measurements performed in $0.1 \%$ SDS solution, ( $\square$ ) measurements performed in water.

$1-2 \%$ instead of $0.8 \%$ ). Consequently, the concentration was slightly underestimated in SDS. However, the error was always lower than $10 \%$ and was not found significantly different by statistical analysis. This lies within the acceptable limits as defined by Malvern Instruments, considering that SDS is present besides particles. It is still advised to use SDS to dissociate clusters, especially for homogenized milk fat globules. Comparing apparent and actual concentrations is sometimes used to estimate the absorption coefficient, and it was found that homogenization and dispersant did not induce major differences in the correlation [8].

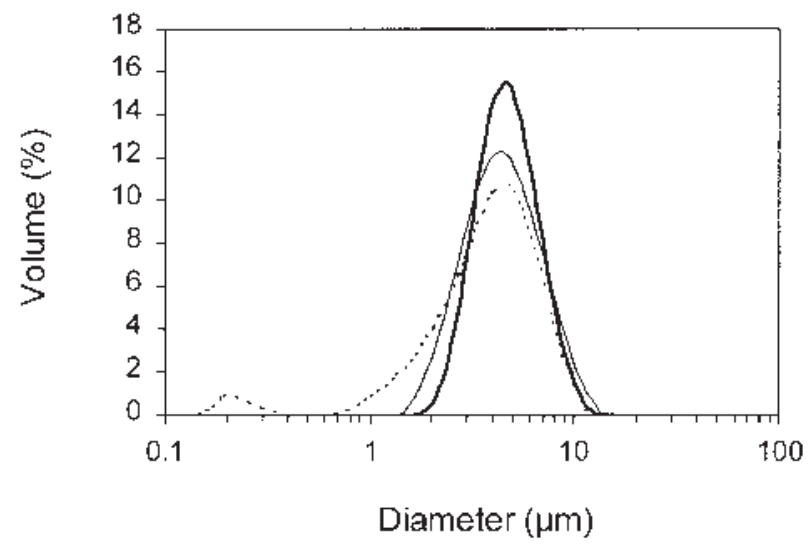

Figure 5. Milk fat globule size distribution using $n_{i}{ }^{\text {corrected }}=1.458$ at $633 \mathrm{~nm}$ and $n_{i}{ }^{\text {corrected }}=1.460$ at $466 \mathrm{~nm}$, and $\mathrm{k}_{\mathrm{a}}=0.0001$ (thick line), 0.001 (thick line), 0.01 (thin line) or 0.1 (dotted line). 
For milk fat globules, $\mathrm{n}_{\mathrm{i}} / \mathrm{k}_{\mathrm{a}}$ such as $1.45 / 0.001$ [8] or $1.46 / 0.01$ [5] were often used with earlier light scattering equipments. Our results show that these mistook $n_{i}$ and overestimated $k_{a}$. Such an error does not influence much the particle size distribution above $1 \mu \mathrm{m}$ but can cause the appearance of artefactual peaks at smaller sizes (Fig. 5 and Ref. [4]). It was not possible to compare directly our results with those of the literature using the same technique, because the latter used only one refractive index at a single wavelength. We did not usually find significant changes in the milk fat globule size distribution whether using partially crystallized globules with $\mathrm{k}_{\mathrm{a}}=10^{-4}$ or melted globules from heated milk with $\mathrm{k}_{\mathrm{a}} \approx 10^{-5}$. However, using liquid milk fat globules typically improves measurement residual. As stated in Section 3.1., it prevents possible scattering by crystals and allows the use of more accurate absorption values. In our opinion, the safest way to proceed is to consider that the milk fat globule $\mathrm{k}_{\mathrm{a}}=0.5 \times 10^{-5}-1.7 \times 10^{-5}$, by using supercooled liquid globules at $20^{\circ} \mathrm{C}$ from the previously heated milk sample.

For large milk fat globules such as natural ones, using the corrected $\mathrm{n}_{\mathrm{i}}$ did not influence results significantly compared to the true $n_{i}$. However, the correction of refractive indexes was beneficial to results with homogenized milk fat globules. The measurement residual was smaller and peak selectivity was improved at submicronic sizes (peaks were similar to those obtained using other methods, namely, Dynamic Light Scattering - results not shown).

\section{CONCLUSION}

To measure milk fat globule size distribution using LLS apparatus:

(i) $\mathrm{n}_{\mathrm{i}}=1.470$ at $466 \mathrm{~nm}$ and 1.460 at $633 \mathrm{~nm}$ are average values for milk fat globules. (ii) If the true refractive index of water at both wavelengths cannot be used in the LLS instrument, it is safer to correct the $n_{i}$ of milk fat so that the difference $\mathrm{n}_{\mathrm{i} \text {,fat }}-\mathrm{n}_{\mathrm{i} \text {,water }}$ remains correct (e.g., if 1.33 is taken for water, use 1.460 and 1.458 for fat at 466 and $633 \mathrm{~nm}$, respectively).

(iii) Heating the sample to melt fat and then promptly make the measurement at $20{ }^{\circ} \mathrm{C}$ allows the prevention of scattering by crystals and uses the $\mathrm{k}_{\mathrm{a}}$ values of liquid milk fat.

(iv) Artefactual peaks appear at smaller sizes if $\mathrm{k}_{\mathrm{a}}$ is overestimated.

(v) $\mathrm{k}_{\mathrm{a}}=1.7 \times 10^{-5}$ at 466 and $0.5 \times 10^{-5}$ at $633 \mathrm{~nm}$ are average values for liquid milk fat.

\section{ACKNOWLEDGEMENTS}

The authors are grateful to Pr. P. Walstra for helpful advice on refractometry. We are indebted to Dr. Drilleau (Laboratoire de Recherches Cidricoles, INRA, Le Rheu) for lending us the refractometer. D. Sainmont is acknowledged for his technical assistance.

\section{REFERENCES}

[1] Handbook of Chemistry and Physics, 71, CRC Press, Boca Raton, USA, 1991.

[2] Fontecha J., Diaz V., Fraga M.J., Juarez M., Triglyceride analysis by Gas Chromatography inassessment of authenticity of goat milk fat, J. Am. Oil Chem. Soc. 75 (1998) 1893-1896.

[3] Griffin M.C.A., Griffin W.G., A simple turbidimetric method for the determination of the refractive index of large colloidal particles applied to casein micelles, J. Colloid Interface Sci. 104 (1985) 409-415.

[4] Guimberteau F., Leal Calderon F., Granulométrie des émulsions de bitume, Bull. Lab. Ponts et Chaussées 222 (1999) 13-22.

[5] Hardham J.F., Imison B.W., French H.M., Effect of homogenization and microfluidization on the extent of fat separation during storage of UHT milk, Austr. J. Dairy Technol. 55 (2000) 16-22. 
[6] Hiemenz P.C., Rajagopalan R., Principles of colloid and surface chemistry, 3, Marcel Dekker, New York, 1997.

[7] Hillbrick G.C., McMahon D.J., Deeth H.C., Electrical impedance particle size method (Coulter Counter) detects the large fat globules in poorly homogenized UHT processed milk, Austr. J. Dairy Technol. 53 (1998) 17-21.

[8] McCrae C.H., Lepoetre A., Characterization of dairy emulsions by forward lobe laser light scattering - Application to milk and cream, Int. Dairy J. 6 (1996) 247-256.

[9] Mehaia M.A., The fat globule size distribution in camel, goat, ewe and cow milk, Milchwissenschaft 50 (1995) 260-263.

[10] Mulder H., Walstra P., The milk fat globule. Emulsion science as applied to milk products and comparable foods, Commonwealth Agricultural Bureaux, Farnham Royal, Bucks., UK, 1974.

[11] Ollivon M., Perron R., Propriétés physiques des corps gras, in: Karleskind, A. (Ed.), Manuel des corps gras, Lavoisier, Paris, 1992, pp. 433-529.

[12] Patton S., Huston G.E., A method for isolation of milk fat globules, Lipids 21 (1986) 170-174.

[13] Pouliot Y., Paquin P., Robin O., Giasson J., Étude comparative de la microfluidisation et de l'homogénéisation sur la distribution de la taille des globules gras du lait de vache, Int. Dairy J. 1 (1991) 39-49.

[14] Wade T., Beattie J.K., Electroacoustic determination of size and zeta potential of fat globules in milk and cream emulsions, Colloid Surface B 10 (1997) 73-85.

[15] Walstra P., Light scattering by milk fat globules, Neth. Milk Dairy J. 19 (1965) 93-109.

[16] Walstra P., Over de brekingsindex van melkvet [Some data on the refractive index of milk fat], Neth. Milk Dairy J. 19 (1965) 1-7.

[17] Walstra P., Estimating globule-size distribution of oil-in-water emulsions by spectroturbidimetry, J. Colloid Interface Sci. 27 (1968) 493-500.

[18] Walstra P., Studies on milk fat dispersion. II. The globule-size distribution of cow's milk, Neth. Milk Dairy J. 23 (1969) 99-110.

[19] Walstra P., Physical chemistry of milk fat globules, in: Fox P.F. (Ed.), Advanced Dairy Chemistry Vol. 2: Lipids, 2 ed., Chapman \& Hall, London, UK, 1995, pp. 131-178.

[20] Walstra P., Borggreve G. J., Note on the refractive index of individual milk fat globules, Neth. Milk Dairy J. 20 (1966) 140-143.

[21] Walstra P., Jenness R., Dairy Chemistry and Physics, Wiley, New York, USA, 1984. 